\title{
THE ACTOR-NETWORK THEORY IN THE CONTEXT OF PlaCE-BASED PEDAGOGY
}

\author{
AGNIESZKA WIESZACZEWSKA \\ Faculty of Pedagogy, University of Wroclaw \\ ul. J. W. Dawida 1, Wroclaw, Poland \\ E-mail address: awieszaczewska@gmail.com
}

\begin{abstract}
Aim. The aim of this article is to provide a theoretical reflection about space (and place) as a topic that is often the focus of researchers representing social and humanistic fields. Analyses of the significance of places to individuals and groups are carried out also on the basis of pedagogy.

Method. The article is based on extended literature review. The most important subdiscipline of pedagogy, which was inspected, was one which particularly emphasises the role of place: "place-based pedagogy", and, on the Polish ground, so-called "pedagogika miejsca".

Results. Research showed clearly, that pedagogues are interested in ways of giving meanings to places by their users, connections of the arrangement of space with its reception by individuals, space valorising and so on. In this article, the author presents also the theoretical perspective of post-constructivism and the actor-network theory proposed by B. Latour and then developed and modified by other researchers, which is one of the most well-known (and recognised) strategies of a post-constructive reflection on reality.

Conclusion. The investigated perspective can successfully become an approach in which pedagogical research related to the spaces in which people operate would be carried out, which would be a valuable complement to pedagogical considerations on place that have been known to date as of the phenomenological perspective.
\end{abstract}

Key words: post-constructivism, ANT, actor-network theory, space, place.

\section{THE PEDAGOGY OF THE PLACE: WHY PLACE MATTERS?}

Place-based pedagogy emerged in the Polish pedagogical reflection in the greatest part thanks to Maria Mendel and her scientific community, which is focused around the University of Gdańsk. Nowadays, all Polish pedagogues who prepare works on place refer to the Gdańsk scholar, who is also the editor of the multi-faculty monograph "Pedagogika miejsca" (Mendel, 2006). She proposes the establishment of a new subdiscipline within pedagogy, a subdiscipline which could be place-based pedagogy. The legitimacy of its existence is explained by the fact that "place is always significant. "Everything" has its place. Somewhere events are going on, somewhere the senses take place, 
through which senses we conceive reality, and we conceive ourselves in that reality, with a more or less clear yet always present sense of connection with place" (Mendel, 2006, p. 21). The importance of undertaking a reflection on the ground of pedagogy is also associated with the increasing changes in its use and the dynamic growth of non-places that modern people are faced with (Danilewicz, 2016, p. 87). Place-based pedagogy is particularly strongly associated with social pedagogy, as it is the one which deals with the pupils' living environment understood as their surroundings, which is very often a "source of self-identification of social entities" (Cichoń, 2014, p. 131), and place-based pedagogy is also supposed to develop as a subdiscipline within its networks.

Place subjected to a pedagogical reflection is a concrete and specific part of space, gaining importance through everyday human experience. It may be a family home, a school, a little homeland - a village, a housing estate, a street, as well as places belonging to the public sphere: "Place is where our lives go on, where we are, including all the ontological aspects of the meaning of existing. If the "world" is understood as an indefinite, untouched space which is only sensed, "our world" will consist in places that remember our presence, bearing its traces, meaning what we think, speak about it, spinning life narratives, living our own lives" (Mendel, 2006, p. 22).

In these words, one can find a reflection of the thoughts of Yi-Fu Tuan, to which M. Mendel also refers in her texts, as well as the classic binary opposition being used, inter alia, on the basis of cultural anthropology, namely "self-stranger". In this particular example, we will talk about creating the opposition of the known world and the external world - the foreign one (orbis interior and orbis exterior). Place-based pedagogy will not be focused on geographic place - because, as Florian Znaniecki wrote in 1938, "human subjects never experience any universal, objective, quality-free, unchangeable, unlimited and unlimitedly divisible space" (Znaniecki, 1938, p. 90). Of course, space, through its physical dimension, is to some extent independent of social valuations. However, "every physical element of space, each of its physical features: dimensions, location, shape, structure, colours, access to light, objects introduced to it, etc., is a dynamic sign, of which semiotics creates relations between individuals, their identity, knowledge, biographical sense and perspectives" (Klus-Stańska, 2015: 42). Therefore, place can be understood as a specific combination of physical landscapes, their social constructs and performances, and emotional ties that influence and shape the worldview of a person. Reading all these nuances of places is the task of place-based pedagogy where "pedagogical places are not general places but are intentional, normative places, which are to serve the realisation of the pedagogy of autonomy. For this reason, a pedagogical place is synonymous with a pedagogical action" (Puchert, Kurowska-Susdorf 2016: 33).

M. Mendel strongly emphasises the need to consider the connection of pedagogy, politics and local social practices, and emphasises the role of cultural animation, in which she distinguishes "animation sensitive to place" (Mendel, 2006, p. 21). She also talks about the fact that a pedagogical reflection on place must be complemented by a philosophical reflection. However, place-based 
pedagogy is not only a reflection about place and its upbringing nature, but also a postulate of educational practical initiatives that should take place in relation to place. This is in line with Doris Bachmann-Medick's reflection, which emphasises that a spatial turn was strongly related to the action and did not focus solely on the problems of discourse: "the spatial perspective significantly delineates a clearance, which finally re-opens the access to materiality, action, change, in research, as space here is understood not so much as a problem of discourse, but rather as a social construction" (Bachmann-Medick, 2012, p. 336). Such a course of action also refers to place-based pedagogy described in the previous chapter, which is very closely related to the practical projects that are found in both formal and informal education.

In M. Mendel's vision, an important dimension of the functioning of the modern man is the place closest to the individual, the place where they live and experience life. Tomasz Szkudlarek wrote about the return of interest regarding the local place, noting that now we are experiencing an unbelievable renaissance of localities, little homelands, ethnic roots, neighbourhoods, and landscapes. This has a great cultural and political significance and is associated with hopes for the reconstruction of democracy and the reconstruction of identity exhausted by conflicts in the sphere of existing, more vast identifications" (Szkudlarek, 1997, p. 151). T. Szkudlarek sees the possibility of regaining the strong human identity based on a narrow, specific location in a situation in which the so-called Grand Narratives (derived from French les grands récits) have been depleted and no longer play an important role in identity processes. Jean-François Lyotard, who announced the demise of the large Enlightenment meta-narratives in his work "The Postmodern Condition: A Report on Knowledge", inspired a number of thinkers who applied his concepts in their own research. Thus, the twilight of the twentieth century was supposed to bring not only the fall of faith in the triumph of liberated reason or history perceived as progress, but also the crisis of faith, nationalism and other stories that were to be the key to explaining all other histories. Man faced the crisis of identity: his existence could no longer be translated through the categories cited above. So, wondering began regarding how an individual can now anchor in reality and build they own stories about themselves. Locality is perceived as one of the remedies for the diagnosed situation.

Globalisation is another process characteristic of modern times. Depending on the perspective of an individual perceiving this process, other aspects will be noticed. One of the most commonly cited definitions of globalisation is the one coined by Roland Robertson, who described it as "a process by which the world is becoming more and more "a single place". Therefore, the unit of the analysis of scientific investigations should become a global system, not its components such as a state, nation or religion" (Robertson: after Misiak, 2010, p. 11). The most important effects of globalisation often include the emergence of transnational corporations, a decline in the importance of nation-states in the international arena, the homogenisation of culture, the Americanisation of culture with the functioning of cultural patterns to a certain extent (Kacz- 
marek, 2014, pp. 39-44). Changes are observed both at global and local levels. Traditional behaviour and authorities may no longer be attractive in a world where increasingly more standards and values are shared and in which tastes are often shaped by modern media. Additionally, it can also cause confusion regarding the expected ways of life. In this situation, "the retreat towards locality is (...) a reaction to the growing uncertainty of the social world. The growing differentiation of cultural space, related to the domination of visual media, evokes and also takes such an effect that, in the flood of detail related to all possible places in the world, we are ever increasingly more often concerned only with the detail of our own place. This is a reduction of a mosaic to its element, a holographic concentration of the world to one point on the map. (...) [I]t is for local communities that are to constitute a reference point for a practical educational and political action in the situation of the Grand Narratives crisis, which has so far guaranteed the validity of decisions" (Szkudlarek, 1997, p. 152). By the unlimited possibilities of acquiring, moving, accepting any patterns of life, it is our own closest place that often becomes the only fixed reference point we care about. For this reason, such places gain enormous pedagogical potential, and educational and animation actions conducted not only in them but also in relation to them "can gain inspirational, theoretical roots and, as a result, assume original forms of individual and social self-creation" (Mendel, 2016, p. 22).

Locality, my "here and now", is very often the only real public sphere of action accessible to man. The crisis of nation-states, progressive globalisation and integration within huge, anonymous administrative political creations (e.g. the European Union, NATO, the Visegrad Group, and also the Warsaw Pact) alienate the individual and at the same time bring them closer to a specific, known and inhabited (in the Heideggerian sense) place. At the other extreme of locality, there is an abstract global reality, and the effect of the tension between locality and globality is called glocalisation (Miszczak, 2013). The closest place can still be realistically co-created by the people who live in it. This happens not only through participation in official actions that are happening in a given area, but also in everyday social practices.

\section{POST-CONSTRUCTIVISM - CAN "NON-HUMANS" TAKE ACTION?}

Every work undertaken by a scientist requires methodological awareness, and one of the proofs of its possession is to realise the existence of paradigms in the social sciences and the humanities, which not only set standards and safeguard the methodological rigour, but also, which is probably even much more significant, are connected with specific beliefs regarding epistemology, ontology, and also concern the ethics of the research itself and what happens to them at later stages (and thus the final development of data, its presentation, distribution). It can be said that the chosen paradigm embeds the research work 
in a broader context, while affecting many decisions made by the researcher at all stages of project work. At present, on the basis of qualitative research, there are often five main paradigms spoken of; they were distinguished by Egon Guba and Yvonne Lincoln (positivism, post-positivism, constructivism, critical theory, and participatory research) (Guba, Lincoln, 2009, p.).

The same term "paradigm" was permanently introduced into the scientific research dictionary by Thomas Kuhn, who saw it primarily as a certain scientific community (understood as beliefs adopted by a given group of scientists on the subject of reality and the possibilities of researching it) as well as a pattern of scientific activity. In this latter sense, the paradigm will be "widely recognised scientific achievements that at some time provide a scientific community with model problems and solutions" (Kuhn, 2001, p. 10). Today, the paradigm in relation to research activity is understood most often as a philosophicalanthropological worldview, which defines (often unconsciously, in part) the most important beliefs of a researcher as regarding reality and how it should be studied. A researcher deciding to conduct research in a given field cannot be limited only to methodology itself, but must also extend to the ontological, epistemological and ethical assumptions that relate to a given paradigm. As Dariusz Kubinowski warns, in the case of limiting oneself to methodological choices only, would lead to "the final separation of empirical science from philosophy, which would be the beginning of its end in humanistic culture and would change it into the technique of collecting and analysing data for instrumental purposes" (Kubinowski, 2013, p. 86). According to Magdalena Ciechowska, a conscious choice of paradigm is crucial for all research instances and should also influence all steps made by a researcher during the implementation of a research project (Ciechowska, 2017, p. 29).

A paradigm that I would like to present constitutes a post-constructivist paradigm which, although not distinguished in all the best-known systematics of paradigms (including of Guba and Lincoln), has for some time been signalled as a new approach in the science of social reality. Post-constructivism is especially present in sociological considerations concerning scientific knowledge, in which "instead of the truth, certainty or objectivity of scientific theorems, the (...) gradually achieved repeatability and stability of research results are placed at the centre of interest" (Binczak, 2013, p. 47). However, I believe that such a shift of emphasis on research interest represented by post-constructivism will be cognitively valuable also in a scientific reflection on a number of other topics, also related to both formal and informal education. The poststructuralist standpoint may, in my opinion, complement the research strategies based on constructivist thinking, without denying what this trend has achieved, and the prefix "post" itself does not mean in this case the complete abandonment of the constructivist achievements (Markiewka, 2013, p. 100). Although critics sometimes find themselves in the expansion of the thought of a post-constructivist attack on what has been developed within the constructivist paradigm (Kowalewski and Piasek 2008, Rydlewski 2014), this trend is rather its modification, considering certain phenomena that have not been 
taken into account yet and thus enabling social and humanist scientists to conduct research using a previously unknown set of assumptions and a dictionary. "We are still "constructivists", but we think that the basic concepts used by cultural constructivists are a bit worn out and we should look for others" (Markiewka, 2013, p. 103). The most well-known notions in question here are all those that are related to the perception of the world as a book, culture as a language, cultural practices as codes.

Jacek Gdula described as post-constructivist all those "trends in contemporary social sciences that depart from thinking in terms of conventions, at the same time not returning to thinking in the perspective of determination, seeking the rights of historical development, or simple empiricism. Post-constructivist theories (...) do not postulate a simple return to measuring reality in the name of believing that it itself exists regardless of what happens between social actors" (Gdula). The best-known proposition in post-constructivism is the actor-network theory, but it also includes a new pragmatism, non-classical sociologies of knowledge, and the latest work of Judith Butler. So, there are many post-constructivisms that deal with the constructivist heritage in different ways (Composing Postcolonial Geographies...). However, the considerations carried out within the framework of these trends combine, inter alia, with the fact that the reality in which we operate resists us and is not characterised by perfect flexibility. Post-constructivism is especially present in sociological considerations concerning scientific knowledge, in which "instead of the truth, certainty or objectivity of scientific theorems, the (...) gradually achieved repeatability and stability of research results are placed in the centre of interest" (Bińczak, 2013, p. 47).

While for the constructivists the most important questions were of an epistemological nature, and thus related to cognition (How does the subject cognise? How does it experience reality? How does it organise its experiences in the narrative? How are the meanings negotiated within the community?), the post-constructivists would be interested in relational ontology: how actors take action together, transform, sustain or weaken their networks (a network is a set of constantly modified relations in which the actor operates). It is not surprising that post-constructivism, which largely grew out of the actor-network theory, presents such questions; its creator, Bruno Latour, was very interested in collectives. He wondered how they worked, how they lasted, when they were stronger and weaker, and how to study them in all their complexity. Looking at the relationship of the object being cognised and the cognising subject has been changed here to thinking about the transformations and mobilisations of heterogeneous networks that comprise humans and non-humans. Post-constructivism recognises the agency of non-human entities, and thus exceeds one of the most important ontological-epistemological principles of constructivism: the division into nature and culture. Culture for the post-constructivists is above all a set of practices, not an autonomous (and better) being towards nature, which was one of the constitutive beliefs inherent in the reflection cultivated since the Enlightenment. "Simply put, the project of modernity does not realise that there is a con- 
stant reconstitution of the community as it excludes the possibility of transforming what is natural, by what is social, political or cultural, and simultaneously does not take into account the fact that the cultural area itself is constituted not only by standards, values, ideas or interpretations, but its duration depends on practices that mobilise the world or on non-human factors" (Wróblewski, 2012, p. 445). Of course, efficiency is not equated with the intent of action; it is also very important that post-constructivists constantly emphasise that all actors, both human and non-human ones, operate in broader or narrower networks and operation is a property of the entire network, not of an isolated factor. This is not about negating the fact that people live and are subject to social conventions and mental beliefs about the world, but non-human factors should also be taken into account when we are interested in the practices of mobilising and destabilising the network. As B. Latour states: "we are talking about the politics of things, not an outdated discussion about whether words refer to the world. They do refer, of course" (Latour, 2013, p. 420). The French philosopher argues that everything that surrounds us is real, true, being at the same time manufactured, constructed, or, to use the term proposed by B. Latour, fabricated (Bińczak, 2010, p. 242). On the example of the famous history of Ludwik Pasteur, he shows that in order for something to start existing for humanity, it must be shared, closed and described in a given network of relations. "(Post)constructivism does not proclaim (...) freedom of constructing. This position only states that bacteria were beyond the reach of humanity (both cognitively and in terms of practical coping with them), until they were placed in the area of human praxis" (Bińczak, 2010, p. 243).

To sum up what has been said, the three most important points of disagreement between constructivists and post-constructivists are as follows:

- the division into culture and nature, which were supposed to be opposites,

- the division into the object being cognised and the cognising subject and the leading role of the epistemological relation, also in relation to the process of the social constructing of reality (constructivist attitude) and the perception of the world as if in action, thanks to which one can break chains binding them with the metaphor of constructing the world without falling into naive realism and return to Reality (post-constructivism),

- the issue of non-human actors' agency (Wróblewski, 2014, p. 456).

Post-constructivism breaks one more opposition, which permanently found its place in the humanistic reflection: the overwhelming thought of the situation of an individual entangled in the system (understood in various ways), which means that no change can take place in principle. It turns out that re-formulating thoughts about reality following the thought of post-constructivism results in a change in the perception of the autonomy (and lack thereof) of the subject, and "the theories we are talking about are, in today's situation, something that is increasingly opening to the search for social change. Thinking in terms of post-constructionism makes us think about the existence of many social actors, not just the relationship of system and individual. In all construc- 
tivist theories, there are categories of discourse, system, society, knowledgeauthority, of something that organises social relations and makes the subject cease to be autonomous. When we steer to post-constructivism, we do not see only the tragedy of an individual who must free themselves. This trend takes up the challenge of analysing the reality of many actors, faces the question of what the relationships between them are, how flexible they are, and how the transition from a particular interest to a universalised rate takes place. Thanks to this, there is the possibility of thinking about the involvement of science in social change. Reality becomes more appealing. It is worth investigating, because you feel that you can change it a bit" (Gdula 2013).

Such an attitude opens the possibility of thinking that social change is possible; strong criticism, based on indicating the totality and omnipotence of the system, very often gives rise to powerlessness. However, when we see that reality is "settable", and any type of engagement gives a chance for a real social change, then the interest in engagement and sense of an individual's agency increases. Network reconstruction is a common phenomenon; certain actors gain strength, others completely stop being significant, alliances once unthinkable to happen are formed, all before our eyes; it may happen that a stable network will be completely disintegrated - this view allows us to rethink the role of science in the context of social change.

\section{BASIC ASSUMPTIONS OF THE ACTOR-NETWORK THEORY}

David Silverman describes theory as "an ordered set of concepts used to define and explain a certain phenomenon" (Silverman, 2008, p. 137). Nowadays, we observe the rivalry of many different theories that propose alternative ways of perceiving the same reality, different dictionaries and strategies of scientific conduct. One of them is the Actor-Network Theory (ANT), which emerged in the 1970s and has been gradually gaining new supporters, proposing a novel, non-anthropocentric way of perceiving and describing reality. Initially developed as part of studies on science and technology, over the years it began to be used to analyse further fields of research. The prospect proposed by B. Latour turned out to be quite a revolution, as it overcame a long-term tendency to perceive material objects as passive, without the possibility of constructing culture. The assumptions of the non-anthropocentric humanities have been presented to Polish readers by Ewa Domańska (2012), who notes that Henryk Skolimowski pointed out that the humanities must be characterised by a survival value, and therefore serve the protection of a species, as early as in the 1970s. Adding to this the growing interest in things (study of things, anthropology of things), animals (animal studies), and generally in what is non-human, it is reasonable to say that "one of the greatest challenges that researchers face today is the deanthropocentrisation of the humanities. Obviously, it is not a matter of removing man from research, but rather of moving away from the humanistic vision of a human being as a measure of the universe and the centre of research interests and creat- 
ing a project of non-anthropocentric humanities" (Domańska, 2012, p. 10). Thus, the research activity carried out in accordance with such assumptions takes into account non-human subjects (in Polish literature the term "poza-ludzkie" is also encountered), as well as hybrid subjects (for instance, classical hybrid subjects include a man with a gun, a photographer with a camera, a modern man with a mobile phone, and therefore subjects that acquire new features through their uniting with technology). Buildings, spaces and places can also be included in the above; just like animals, things, or plants, they possess the causative power of creating meanings that then have a real impact on the lives of man and other actors (and thus: they take action. It should be remembered that the causative power in ANT does not have to be related to the intentionality of action). The future-friendly humanities (Domańska, 2012, p. 14) take into account extreme subjectivities, remembering to avoid the trap of talking about them in so far as they are useful to a human being, thus becoming entangled in human discourse and subordinated to our needs.

Although nowadays ANT is referred to using the prefix "post" (Fenwick, Edwards, 2010), it is worth recalling the most important assumptions of the described theory and its analytical capabilities, as well as showing its use in educational research. According to the actor-network theory, one should speak about human and non-human actors who create networks of varying degrees of stability. The Latourian actor is everything that directly affects other actors.

The agents do not create permanent and stable hierarchies, but they do create networks that are constantly changing. Networks are a transitory result of mutual interactions between human and non-human actors (an example can be constituted by Tara Fenwick's key to school classes, which, being placed at the centre of school discipline, authority and control practices, encouraged teachers to mobilise their own networks that were supposed to weaken the network imposed from above, or to make easier living alongside it) (Fenwick, Edwards, 2010, p. 7), which are "both real as nature, narrative as discourse and collective as society" (Latour, 2011, p. 16). These words show one of the most important assumptions of the Latourian theory, namely that it is relationalistic. The actor does not have to navigate the network, but they have to act in it, that is, influence the other elements. As Krzysztof Abriszewski emphasises, the network should be understood as an answer to the question "what makes us stick together" and each actor - as a local network condensation. Furthermore, actors are constantly created in situations in which relations between existing actors become strong and durable enough (Abriszewski, 2012 p. 10).

The element that distinguishes ANT to a great extent is a dictionary developed within its framework, for which notions such as an actor (also known as actant), factish, quasi-object/quasi-subject, human/non-human factors, network, factory, translation, purification, negotiations, collective, black box and others are characteristic. This lexicon not only allows the ANT perspective to be shown in words, but also has the task of avoiding the classic dichotomies such as natureculture, object-subject, theory-practice, which have been strengthened over the years of classical science. As the world is inhabited by hybrids, the language 
of scientists should also adapt to it. In his considerations, B. Latour went even further, showing that nowadays the "ontological and epistemological aspects cannot be clearly separated, because the properties of beings, their history and the act of cognising constitute one continuous network. The identity of all actors is constantly changing; their stability and continuity of existence must be maintained in networks of relations by other actors. We can only speak about the essence of an object when the process of its creation has been completed and the network has been locally stabilised" (Bińczak, 2005, p. 96). An open, hybrid, nonheterogeneous and indefinite world has to be cognised through a research strategy that is not characterised by a priori, reductionistic assumptions that a certain part of our reality is social and the rest of it belongs to nature (which, of course, is almost automatically associated with evaluation and hierarchy). Therefore, ANT assumes that every actor obtains their reality and form (efficiency) only in action, and beyond the network of connections they are unstoppable.

This fundamental conviction of the symmetrical sociology proposed by B. Latour (which is to depart from researching only the social elements) - a departure from the dualistically perceived world, is not easy to accept. Modernity has validated the division of reality into two spheres: a human sphere and a non-human sphere, while the task of man was to name the other sphere, to describe it, to explore it, and thus to master it (https:/ / stosowana.wordpress. com). This drastic split, initiated by the philosophy of Immanuel Kant, in later years was most often tacitly accepted and rehashed, and phenomenology and Darwinism were among the most influential trends trying to bring man and the world closer together. In addition to the characteristic, and very hermetic, dictionary and revolutionary claims regarding reality, the actor-network theory is not easy to describe as the creators themselves did not want to create its closed rules, something like an ANT toolkit, which would perhaps make its reception easier (Fenwick, Edwards, 2010, p. 2). Then, it turns out that "the ditch dug up between ANT and more traditional theories of culture may seem like a real precipice" (Abriszewski, 2015, p. 99).

The nature of the surrounding reality is further emphasised by the appeal of B. Latour to move away from the term "society" in favour of community. Such a language operation is emphasised by the fact that "(...) we are starting to look at the common world in a wider perspective, taking into account not only people or groups, categories or social classes, but also what is non-human, and takes action in the collective world, e.g. objects or technologies" (Abriszewski, Frąckowiak, 2012, p. 176). Therefore, ANT deals not with the essences of actors (who/what they are), but with how they work and how they enter into relations. "In the framework of the actor-network theory, the essences of beings are not ready or found as-are, but they are understood as often transitory results of the stabilisation of the network" (Binczak, 2005, p. 95). The actor is inseparably connected with the history of their cognition, which affects their identity and essence. An almost canonical example of the emergence of a new, non-existing actor is the Latourian example of L. Pastreur and his work on yeast. As B. Latour argues: "Pasteur designs rehearsals for the actor to show their characteristics. Why is 
the actor defined by rehearsals? Because there is no other way to define an actor than through their actions, just as there is no way to define actions other than by investigating which other actors have been modified, transformed, worried or created thanks to the character that is of interest to us" (Latour , 2013, p. 53), and further argues that "a being is an existence and an existence is an action" (Latour, 2013 , p. 159). The perception of actors by their stabilisation in the network rather than by ontology makes it possible to talk about them not so much as points but trajectories. It is also important that the networks (which are characterised by their length, and therefore the number of actors involved in them, and the stability - how expensive it is to dismantle it) are not created solely by social entities, that is why we are talking about social nature.

Of course, advocates of the actor-network theory do not deny the validity of ontology; the relationalism of this theory only emphasises the fact that the methods, strategies and strength of the established relations between the elements of a network should be more privileged in the research process than the elements themselves. The motto that advocates ANT is "follow the actors", which results from the fact that, "according to Latour, it is necessary to develop the anthropology of science, design field studies and enter laboratories. The anthropological method allows one to conduct research without being obliged to share the concepts and competences of observed researchers. One should follow the actors themselves by observing their actions, without making any additional assumptions about the reality or unreality of the observed relationships" (Bińczyk, 2005, p. 93).

\section{SUMMARY - SUBCONSTRUCTIVE APPROACH AND EDUCATIONAL RESEARCH}

I decided to present the actor-network theory in the perspective of pedagogical research on place, because it is a particularly valuable cognitive strategy in a situation where we look not at specific objects, but seek the answer how different elements of reality come together into relations, creating a dynamic network full of tensions. It is true that B. Latour himself developed the actor-network theory to study science, stressing that in the same way one can also talk about technology as it also works through a series of translations. However, studies that have already been carried out on various areas related to education show that the actor-network theory can also be verified in pedagogical studies. Although such studies already exist, as underlined by T. Fenwick and Richard Edwards, ANT is not widely used in education and upbringing studies, although the efforts made so far allow us to conclude that it is a productive perspective (Fenwick, Edwards, 2010, p. 1). The inclusion of the ANT perspective would even allow one to see how material objects influence educational processes, especially in the context of, as Lucyna Kopciewicz called it, "cyborgisation of education" (Kopcewicz, 2016, p. 148). However, if we look at the actor-network theory as "a research approach specialising in searching, tracking, tracing, developing and describing (...) transitions between states of negotiations/order" (Abriszewski, 2015, p. 106), 
then a wide range of research areas, going beyond analysing the increasingly frequent entry of non-human actors into the field of teaching, opens in front of the researcher of educational processes.

Place was previously perceived first of all in the phenomenological perspective, and the most important research questions, which individuals conducting the research on place/space wished to address, concerned the way in which it was valorised, what the course of processes of giving meaning to it was, who was involved in them. The inclusion of a post-constructivist perspective that involves changing the perception of place as a certain semantic construct to a real acting actor who has the power and the ability to change the network, would allow to extend the perspective in which this is perceived.

\section{REFERENCES}

1. Abriszewski, K. (2015). Co robi filozofia w humanistyce? [What does the philosophy in humanities?]. Filo-Sofia, 15, 43-64.

2. Abriszewski, K. (2012). Poznanie, zbiorowość, polityka. Analiza teorii aktora-sieci Bruno Latoura (Knowledge, collectivity, politics. Analysis of Bruno Latour's Actor-network theory). Kraków: Universitas.

3. Bachmann-Medick, D. (2016). Cultural Turns. Nowe kierunki w naukach o kulturze [Cultural Turns. New Orientations in the Study of Culture]. Warszawa: Oficyna Naukowa.

4. Danilewicz, W. (2016). Doświadczenia miejsca w przestrzeni globalnej - perspektywa pedagogiczna [Experience of the place in the global space - pedagogical perspective]. Pedagogika Społeczna, 59, 81-93.

5. Guba, E.G., Lincoln, Y.S. (2009). Kontrowersje wokót paradygmatów, sprzeczności i wyłaniające się zbieżności [Controversies around paradigms, contradictions and emerging convergence]. In: N.K. Denzin, Y.S. Lincoln (Eds.), Metody badań jakościowych [Qualitative research methods] (pp.281-314). Warszawa: Wydawnictwo Naukowe PWN.

6. Kaczmarek. B., (2014). Ekonomiczne i społeczne następstwa globalizacji [Economic and Social Consequences of Globalization]. Annales. Etyka w życiu gospodarczym, 17, 35-46.

7. Klus-Stańska. D. (2015). Szkolna klasa - miejsce (nie)przyjazne dziecku [School class: child (not) friendly place?]. In: T. Sadoń-Osowiecka (Ed.), Miejsce, przestrzeń, krajobraz. Edukacyjne znaki [Place, space and landscape: educational signs] (pp. 71-82). Kraków: Impuls.

8. Kubinowski. D. (2013). Idiomatyczność - synergia - emergencja. Rozwój badań jakościowych w pedagogice polskiej na przełomie XX i XXI wieku [Idiomatics - synergy - emergence. Development of qualitative research in Polish pedagogy at the turn of the 20th and 21st centuries]. Lublin: Wydawnictwo Makmed.

9. Mendel, M. (2006). Pedagogika miejsca i animacja na miejsca wrażliwe [Pedagogy of space and animation sensitive to place]. In: M. Mendel (Ed.), Pedagogika miejsca [Pedagogy of place] (pp. 21-37). Wrocław: Wydawnictwo Naukowe DSW.

10. Misiak. W. (2010). Globalizacja - więcej niż podręcznik [Globalization - more than a textbook]. Warszawa: Centrum Doradztwa i Informacji Difin Sp.z.o.o.

11. Puchert. J., Kurowska-Susdorf A. (2016). Podmiotowe bycie w mieście. Perspektywa niemieckiej pedagogiki miejsca/przestrzeni [A Subjective being in the city. Perspective of German place / space pedagogy], Studia Pedagogiczne, XIX, 29-50.

12. Szkudlarek. T. (1997). Miejsce, przemieszczenie, tożsamość [Place, displacement, identity]. In: J. P. Hudzik, J. Mizińska (Eds.), Pamięć, miejsce, obecność. Wspótczesne refleksje nad kulturą i ich implikacje pedagogiczne [Memory, place, presence. Contemporary reflections on culture and their pedagogical implications]. Lublin: Wydawnictwo UMCS.

13. Znaniecki. F. (1938). Socjologiczne podstawy ekologii ludzkiej [Sociological foundations of human ecology], Ruch Prawniczy, Ekonomiczny i Socjologiczny, 1,89-119. 